\section{ECONOMICS}

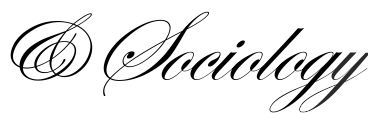

Ona Gražina Rakauskienè, Mykolas Romeris University, Vilnius, Lithuania,

E-mail:ona.rakaus@mruni.eu

Lina Volodzkienè, Mykolas Romeris University, Vilnius, Lithuania,

E-mail:

lina.volod₹kiene@gmail.com

Received: July, 2016

1st Revision: October, 2016

Accepted: December, 2016

DOI: $10.14254 / 2071-$

789X.2017/10-1/19

JEL Classification: D63, E21, P46, D31

\title{
THE INEQUALITY OF MATERIAL LIVING CONDITIONS IN EU COUNTRIES
}

\begin{abstract}
Socio-economic inequality has become one of the most relevant problems in the global economy. Studies carried out in the past 10 years have revealed that a high level of inequality prevents economic growth. The standard means of measuring these differences in equality include methods and aspects such as looking at inequalities in income and consumption, but these criteria do not reflect the actual level of inequality. To find out the actual level of socio-economic inequality, the distribution of wealth should be analysed. However, until now aspects involving the unequal distribution of material living conditions and housing inequality have not been the main objects of sufficient scientific research. For this reason, the main aspects to be analysed in this article are the distribution of material living conditions and housing inequality in Lithuania and other EU countries, with a special focus on the extent and volatility of the problem.
\end{abstract}

Keywords: wealth inequality, socio-economic inequalities, distribution of material living conditions, quality of life.

\section{Introduction}

The quality of life in society is the main factor influencing socio-economic growth. This has mostly been driven by changes in the economic paradigm, as universal monetary methods based on monetary factors and fiscal policies have been replaced by non-orthodox concepts of economic development that emphasise the importance of society's interests and quality of life. The prioritisation of these aspects has led to economic growth and societal satisfaction in EU countries such as Germany, France, Italy, Austria, the Scandinavian countries and Switzerland. At the same time, other countries have underestimated the importance of human resources and still live with the belief that the radical and liberal doctrine of the Washington Consensus - which is criticised more and more - will improve quality of life in society, competitive ability and socio-economic progress. Unfortunately, this might lead to disappointment in existing political systems in various countries and the polarisation of members of society, as well as an uneven distribution of income and resources, high levels of inequality and poverty.

Socio-economic inequality can therefore be considered to have become one of the most relevant problems in the global economy. Studies carried out in the past 10 years (such as those by Stiglitz, Sen, Fitoussi, Reich, Rogoff and the World Bank) have revealed that a high level of inequality prevents economic growth. Reich (2010) stated that the reasons for 
the recent global crisis were not the increase in national debts or people's inability to live within their means, but mainly a high level of socio-economic inequality when growth in GDP is caused by unjustified rise in income among the rich (Rakauskiené, 2015). The report by Stiglitz, Sen and Fitoussi (Report by the Commission on the Measurement of Economic Performance and Social Progress, 2009) revealed that the influence of socio-economic inequality must be analysed in relation to both economic growth and quality of life.

International organisations such as the World Bank, Organisation for Economic Cooperation and Development (OECD), European Commission and Eurostat have carried out studies in relation to socio-economic inequality and quality of life, and their influence on economic development in a particular region or country. The concept of socio-economic inequality has also been researched by Stiglitz, Reich, Atkinson, Piketty, Rakauskienè, Lazutka and others; the concept of wealth has been analysed by Galiniene, Jakutyte்Sungailiené, Pakalniškis and others; wealth inequality has been studied by Chesters, Jurges, Keister, Moller, Simpson, Gollier, Wolff, Bover, Lysandrou, Cragg, Ghayad, Carroll, Young, Wood, Rieger; and aspects involving quality of life have been researched by Puškorius, Servetkienè, Gruževskis, Merkys, Štrimikienè and others. However, it should be noted that the influence of material living conditions on quality of life has not been researched in-depth. The standard means of measuring socio-economic inequality include methods and aspects involving income distribution and inequality of consumption. According to the authors, however, these criteria do not reveal the actual level of inequality. To find out this out, it makes sense to research the distribution of living conditions, which might be referred to as the most adequate criterion that reflects socio-economic inequality.

\section{The Importance of Material Living Conditions in Contemporary Socio-economic Development}

Socio-economic inequality. Socio-economic inequality is the outcome of modernisation within societies and economic development in the contemporary world. It is influenced by various economic (macro) factors (such as economic growth, policies with regard to taxation, social benefits and allowances, labour market policies and regulations, and income distribution), as well as social and demographic factors (such as family size and composition, income, education, qualifications, skills, age, sex, social status and culture) and psychological (micro) aspects (such as a person's characteristics, way of thinking, health and fears). Socio-economic inequality includes all aspects involving wealth and income distribution in societies. Moreover, imbalances in wealth and income in contemporary society lead to uneven opportunities for future generations (Rakauskienè, 2015). Inequalities in income and consumption are the two main concepts distinguished in scientific literature. According to the authors, this kind of distribution is not finite. Figure 1 reveals other equally important aspects of the phenomenon. 


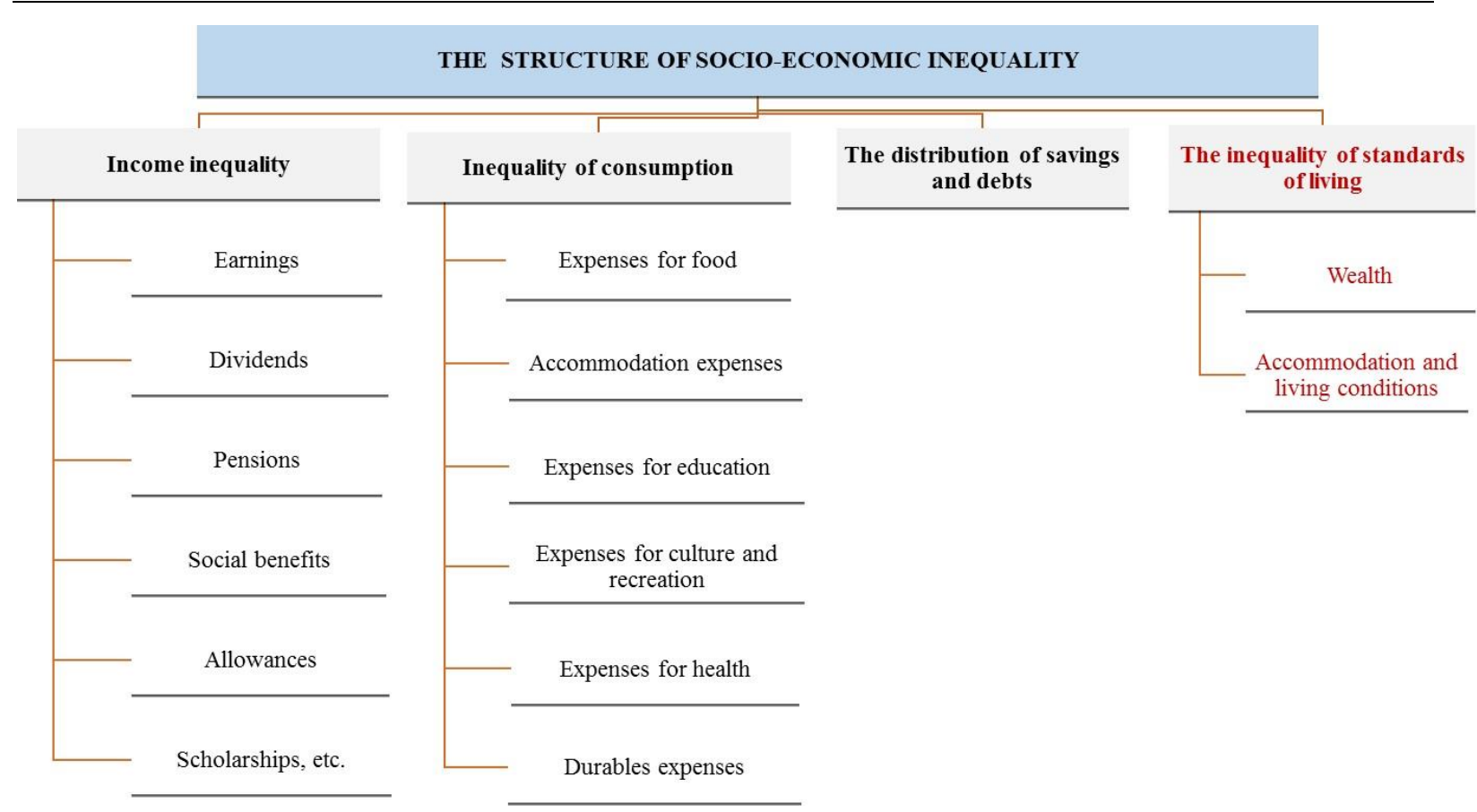

Figure 1. The Structure of Socio-economic Inequality Source: created by the authors.

Socio-economic inequality remains a broad and complex concept, as many talented philosophers, political theorists, sociologists and economists had to rack their brains in order to explain its meaning and possible implications. Economic inequality can be conceived of as inequality with an economic effect or an economic origin, being as much an outcome of the underlying economic process as an input into these processes (Salverda et al., 2013).

In terms of the types of inequality cited, it can be stated that all of them are integral parts of economics that either prevent or increase economic growth and have certain consequences. Moreover, it should be emphasised that inequality is an economic rather than a social problem - in other words, it is a problem that involves the economic system, especially when this becomes excessive and prevents economic progress.

Income inequality - the key economic variable - is one of the most important problems in the realm of socio-economic inequality and among the main subjects in many studies concerning inequality in general. The flow of income is only one part of this problem. The accumulated wealth and its distribution is far more illustrative rate (Salverda et al., 2013). With regard to the distribution of income and wealth, poverty might influence not only disparities between people in relation to those resources, but also in relation to social life being the main reason for discontent with quality of life.

The structure of material living conditions. The most important measure of achievement for every country is economic growth, the dynamics of which are influenced by various factors. An increase in economic potential has its basis in cumulative and newly created wealth (Galinienè, 2005). It should be noted that the term "wealth" might be understood differently in relation to legal, economic, physical, social and other areas, and is defined according to the features and priorities of a particular scientific field. This explains why it is generally such an abstract term (Ragauskienè, 2011).

In economic theory, meanwhile, the term "wealth" includes anything that has a value and is considered personal property (Pakalniškis et al., 2008). In analyses of the concept of wealth, certain separate units or types of wealth are outlined, but a common method for summarising them has never been presented. Criteria that define wealth from an economic 
perspective are the following (Ragauskienè, 2011): 1) wealth must have a value; 2) a person or institution must have ownership rights to an object; and 3) the object must be useful in the future.

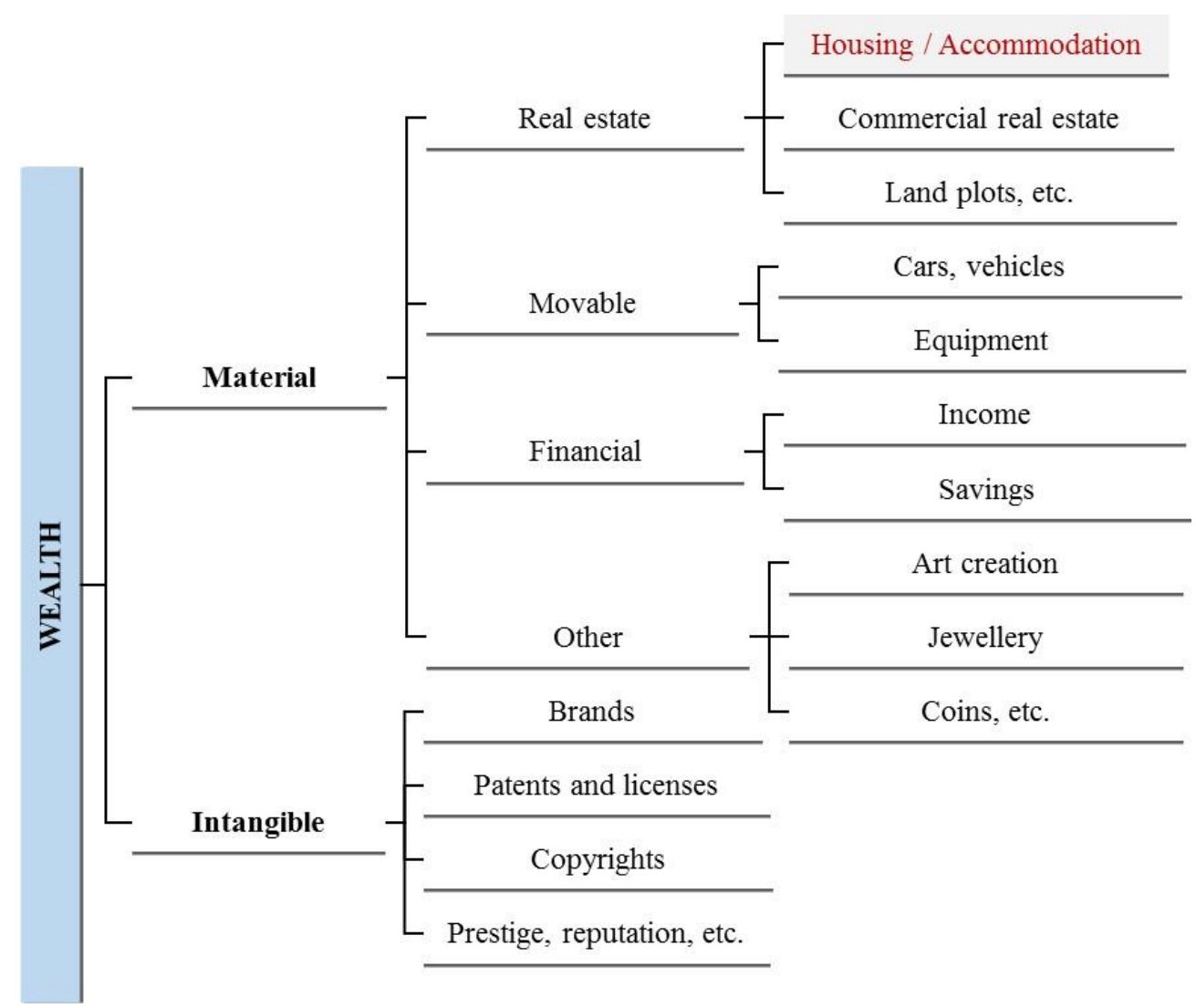

Figure 2. A Classification of Wealth

Source: Created by the authors.

Figure 2 shows an economic classification of wealth created by the authors. In this case, material wealth is the most important factor, with the distribution and correlation between real estate and quality of life emphasising the importance of dwelling place. Meanwhile movable and other type of wealth is considered to be directly related to obtainable income. The opportunity to attain and manage non-material wealth, such as copyrights and licences, in turn depends on the amount of material wealth a person has. This opportunity might emerge if a person has a certain social status or has accumulated a certain amount of material wealth, or in the case of favourable circumstances (for example, inheritance).

The influence of inequalities in income and material living conditions, with a special focus on the importance of dwelling place, has never been analysed and evaluated in relation to quality of life. However, it is presumed that this influence may be huge. To shape a country's political system and ensure the well-being of society and individuals within it, the importance of this must be thoroughly evaluated.

The distribution of material living conditions. Material living conditions and their distribution in society can be analysed using different variables. The main ones include financial indicators such as expenditure, income and wealth, as well as non-monetary indicators such as multidimensional measures of material well-being and happiness, and other variables. Income is not the only indicator of quality of life, and the welfare of households depends on the number of family members and their health, the economic and social 
environment, and economic resources. These resources include human capital and non-human capital - in other words, wealth. It should be noted that wealth is more unequally distributed than human capital, earnings or income. The Gini coefficient for disposable income in OECD countries ranges from 0.30 to 0.50 , compared with a range of 0.50 to 0.80 for the distribution of wealth (Davies, 2013). The top 1\% of families in the United States share over $30 \%$ of the wealth, and based on certain estimates, $50 \%$ of the world's household wealth belongs to $2 \%$ of adults (Davies, 2013). Wealth and income are correlated, so a high level of concentration highlights the problems of socio-economic inequality.

The concept of "wealth" is used in the meaning of all material non-human assets minus debts. In theory, the term includes cash and deposits, other liquid assets, stocks and bonds, business equity, owner-occupied dwellings or any other real estate, and consumer durables, including antiques, art and jewellery. However, in practice not all assets are included-for example, consumer durables are often understood and limited by vehicles. Moreover, the concept of wealth and assets such as consumer durables and real estate are often understood differently in different countries.

Table 1. An International Comparison of Wealth Inequality

\begin{tabular}{lcccc}
\hline \multirow{2}{*}{ Country } & Year & $\begin{array}{c}\text { Share of top } \\
10 \%\end{array}$ & $\begin{array}{c}\text { Share of top } \\
1 \%\end{array}$ & Gini \\
\cline { 2 - 5 } & 2002 & 45.0 & & 0.622 \\
\hline Australia & 1999 & 53.0 & & 0.688 \\
\hline Canada & 1975 & 76.4 & 28.8 & 0.808 \\
\hline Denmark & 1998 & 42.3 & & 0.621 \\
\hline Finland & 1994 & 61.0 & 21.3 & 0.730 \\
\hline France & 1998 & 44.4 & & 0.667 \\
\hline Germany & 1987 & 42.3 & 10.4 & 0.581 \\
\hline Ireland & 2000 & 48.5 & 17.2 & 0.609 \\
\hline Italy & 1999 & 39.3 & & 0.547 \\
\hline Japan & 1988 & 43.1 & 14.0 & 0.579 \\
\hline Korea & 2001 & 51.7 & & 0.651 \\
\hline New Zealand & 2000 & 50.5 & & 0.633 \\
\hline Norway & 2002 & 41.9 & 18.3 & 0.570 \\
\hline Spain & 2002 & 58.6 & & 0.742 \\
\hline Sweden & 1997 & 71.3 & 34.8 & 0.803 \\
\hline Switzerland & 2000 & 56.0 & 23.0 & 0.697 \\
\hline UK & 2001 & 69.8 & 32.7 & 0.801 \\
\hline USA & & &
\end{tabular}

Source: Davies, 2013.

Table 1 shows the international comparison of wealth inequality. Based on this analysis, it is clear that wealth inequality is high in all 17 of these OECD countries. The top $10 \%$ of people in these nations share between $39.3 \%$ and $76.4 \%$ of the wealth, with the Gini coefficient ranging from 0.547 to 0.808 . It should be noted that the results were gathered using different methods, such as surveys, wealth-tax-based estimates and estate-multiplier figures. Considering the variety of methods applied, it remains unclear how cultural differences might have shaped the results. Some of the most significant results are seen in the United States, where share of wealth of wealthiest $10 \%$ of the population share $69.8 \%$ of the wealth and the Gini coefficient is 0.801 . In several other countries where a survey method was applied, the results are similar. Based on wealth-tax and estate-multiplier estimates, 
meanwhile, the share of wealth of wealthiest $10 \%$ of the population in the UK share $56 \%$ of the wealth, and the share of wealth of wealthiest $10 \%$ of the population in Switzerland share $71.3 \%$ of wealth, and the Gini coefficients range from 0.697 (in the UK) to 0.803 (Switzerland) (Davies, 2013).

The impact of wealth inequality on economic well-being depends on the correlation between wealth and income. These two factors are correlated, but are not completely identical. It may be stated that the coefficient of their correlation is about 0.5 (Davies, 2013).

\section{The Uneven Distribution of Material Living Conditions in EU Member States}

An asset is considered to be a unit of wealth only if it has an owner (Galinienè, 1999). The ability to obtain wealth and have it at one's disposal ensures a material and moral feeling of security, self-confidence and self-esteem, and in turn influences quality of life. From a historical perspective, real estate is considered the most valuable type of wealth. Housing is a significant factor in human well-being and helps to ensure stability in a society (Lipnevič, 2012), but this subject has still not been covered thoroughly enough in scientific literature. For example, the distribution of wealth has not been measured and the influence of wealth inequality, with a special focus on the importance of dwelling in relation to quality of life, has not been analysed.

In 2010, EU countries started to implement the 10-year strategy Europe 2020 to help create new workplaces and aid economic growth. The main purpose of this is to increase the EU's competitive ability and maintain its economic model of a social market, while increasing the effective use of resources at the same time. This strategy also seeks to ensure collaboration between EU member states, set priorities and aims, and create a special system to implement those aims. The EU has correlated goals that it is seeking to accomplish by 2020 in five fields: employment; scientific research and development; climate change and energy; education; and the battle against poverty and social exclusion (European Commission, 2014). It has been stated that one of the main challenges faced by Europe 2020 is the reduction of poverty and social exclusion, with a major goal of providing every EU citizen with a decent living place in terms of both price and quality. According to Eurostat researchers, quality of housing is key for a good quality of life, but the lack of appropriate housing is a deep-rooted problem in many EU countries (Eurostat, 2014). It should be noted that there have been no studies that reveal the correlation between wealth attained and quality of life, with a special focus on living place and its quality. However, studies carried out by EU institutions in the last few years that have examined living environments and the condition and quality of housing have revealed that these factors directly influence quality of life.

In 2012, Eurostat completed research into material living conditions and the living environment in EU member states, with a focus on decent accommodation as one of people's most important needs. According to the results of this research, $41.3 \%$ of EU citizens lived in flats, with one-third $(34.1 \%)$ in detached houses and $24.0 \%$ in semi-detached houses. The countries with the largest proportions of people who lived in flats were Estonia $(65.1 \%)$, Spain (65.0\%) and Latvia (64.4\%). Meanwhile, those with the largest proportions of people who lived in detached houses were Croatia (73.0\%), Slovenia (66.6\%), Hungary (63.9\%), Romania $(60.5 \%)$ and Norway $(60.7 \%)$. Semi-detached houses were most popular in the UK $(60.9 \%)$, the Netherlands (60.0\%) and Ireland (59.0\%) (see Figure 3). 


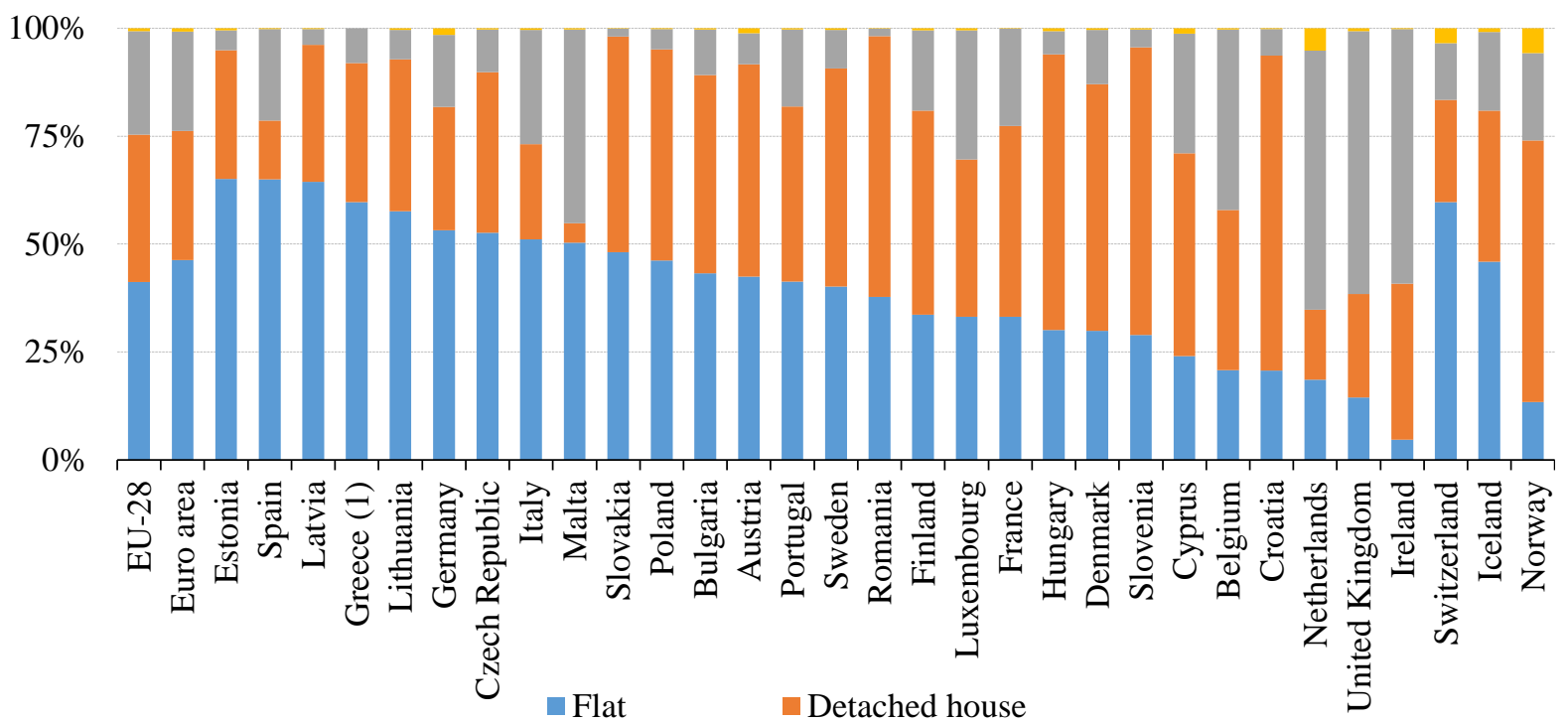

(1) Not significant for "Other" category

Figure 3. The Distribution of Population Based on Housing Type (2012)

Source: Eurostat, 2014.

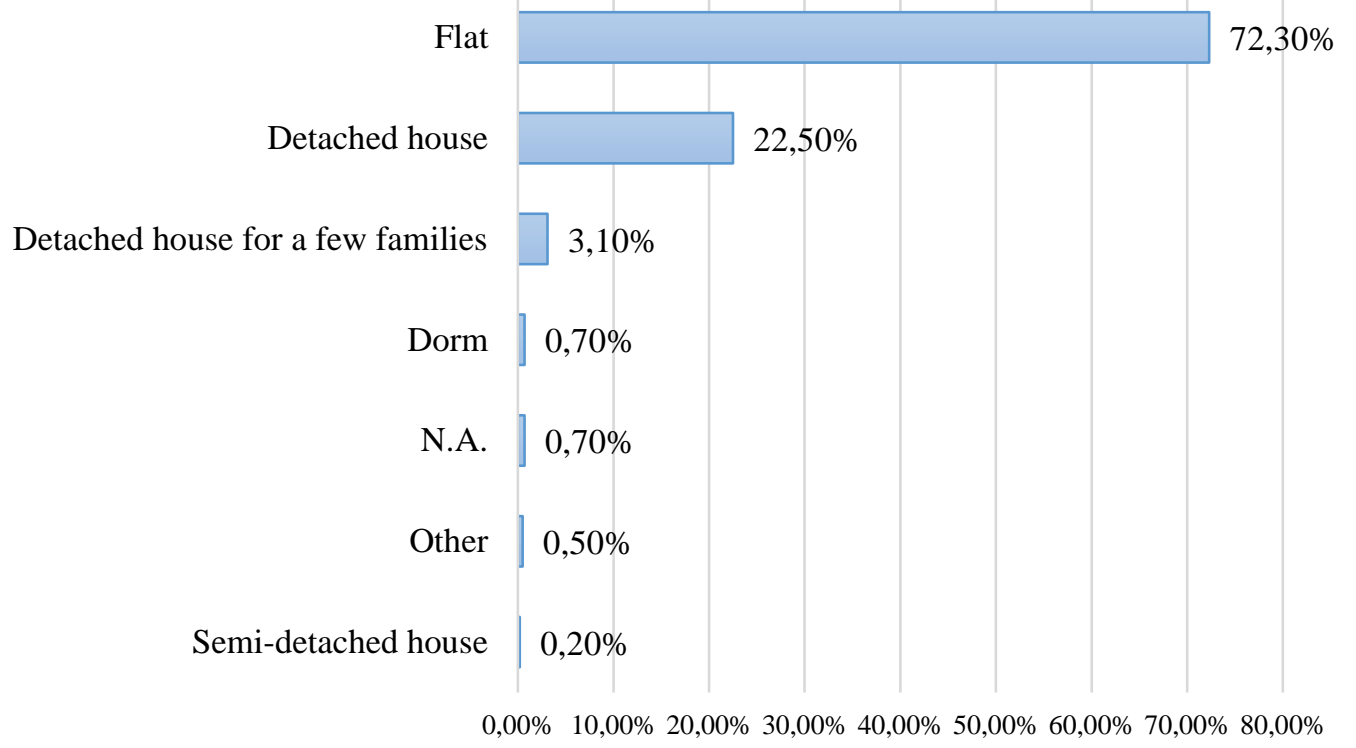

Figure 4. Distribution of Lithuanian Residents Based on Housing Type

Source: Mykolas Romeris University, Vilmorus Market and Opinion Research Centre, 2016.

In 2016, the Vilmorus Market and Opinion Research Centre completed a study on behalf of Mykolas Romeris University showing that $72.30 \%$ of Lithuanian citizens lived in flats. Meanwhile, $22.50 \%$ of citizens lived in detached houses for one family and $3.10 \%$ in townhouses shared with several other families (see Figure 4).

It should be noted that $81.80 \%$ of Lithuanian residents currently live in homes constructed between 1961 and 1990 (see Figure 5). Only 1.90\% of residents proved to be living in relatively new buildings (from 2001 and later). Based on these trends, an assumption might be drawn that the majority of Lithuanian residents are lack high-quality housing or are unable to obtain it and they therefore face various exploitation issues. 


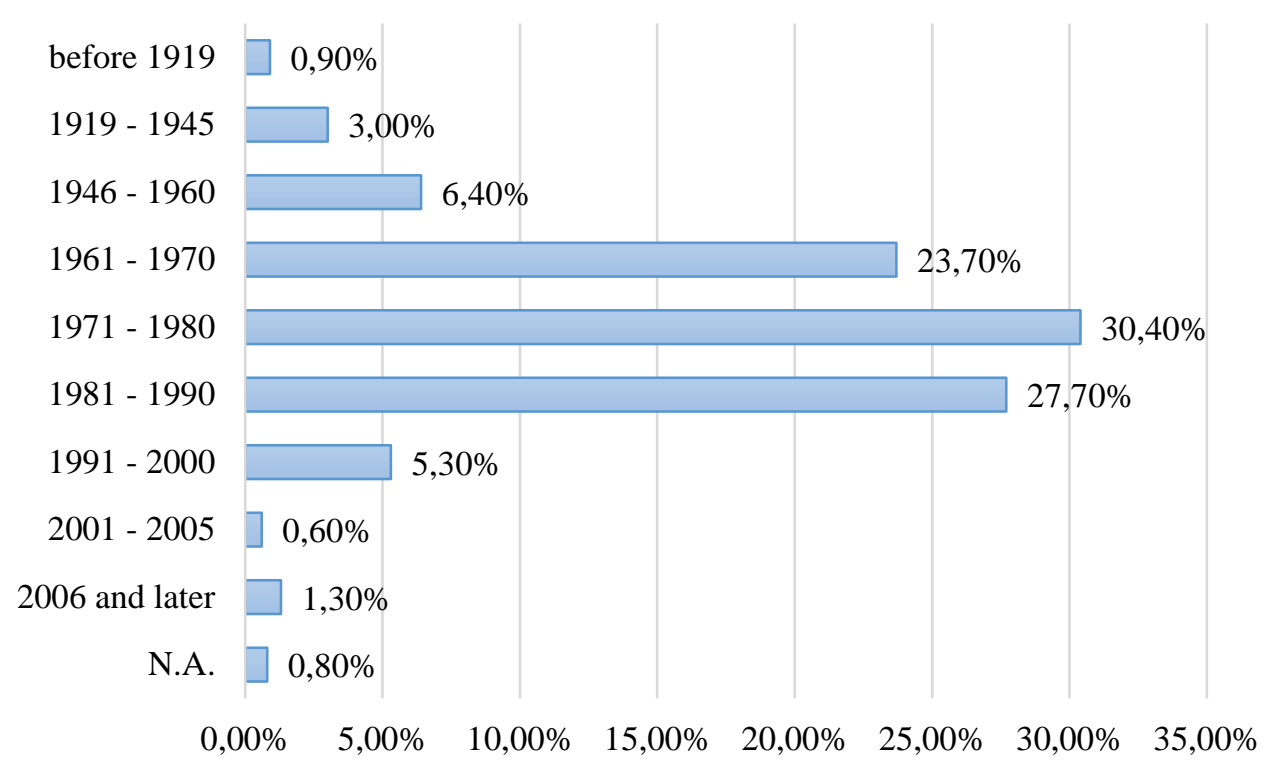

Figure 5. Homes According to Their Year of Construction

Source: Mykolas Romeris University, Vilmorus Market and Opinion Research Centre, 2016.

The housing cost overburden rate, which is calculated by Eurostat, should be taken into consideration because this reveals the percentage of all households in which housing expenditure constitute more than $40 \%$ of equivalised disposable income (see Figure 6).

In $2012,11.2 \%$ of citizens across the $28 \mathrm{EU}$ member states lived in households in which more than $40 \%$ of disposable income was spent on housing and its maintenance. In Greece, Denmark, Germany, Romania, Bulgaria and the Netherlands, the norm of the rate was exceeded by $14.0 \%$, whereas the lowest rates were observed in Cyprus (3.3\%) and Malta (2.6\%). In comparison with 2011, the housing cost overburden rate across the $28 \mathrm{EU}$ member states decreased by 0.4 percentage points in 2012. In contrast, the rate increased in Greece (by 8.9 percentage points), Romania (6.6 percentage points) and Bulgaria (5.8 percentage points).

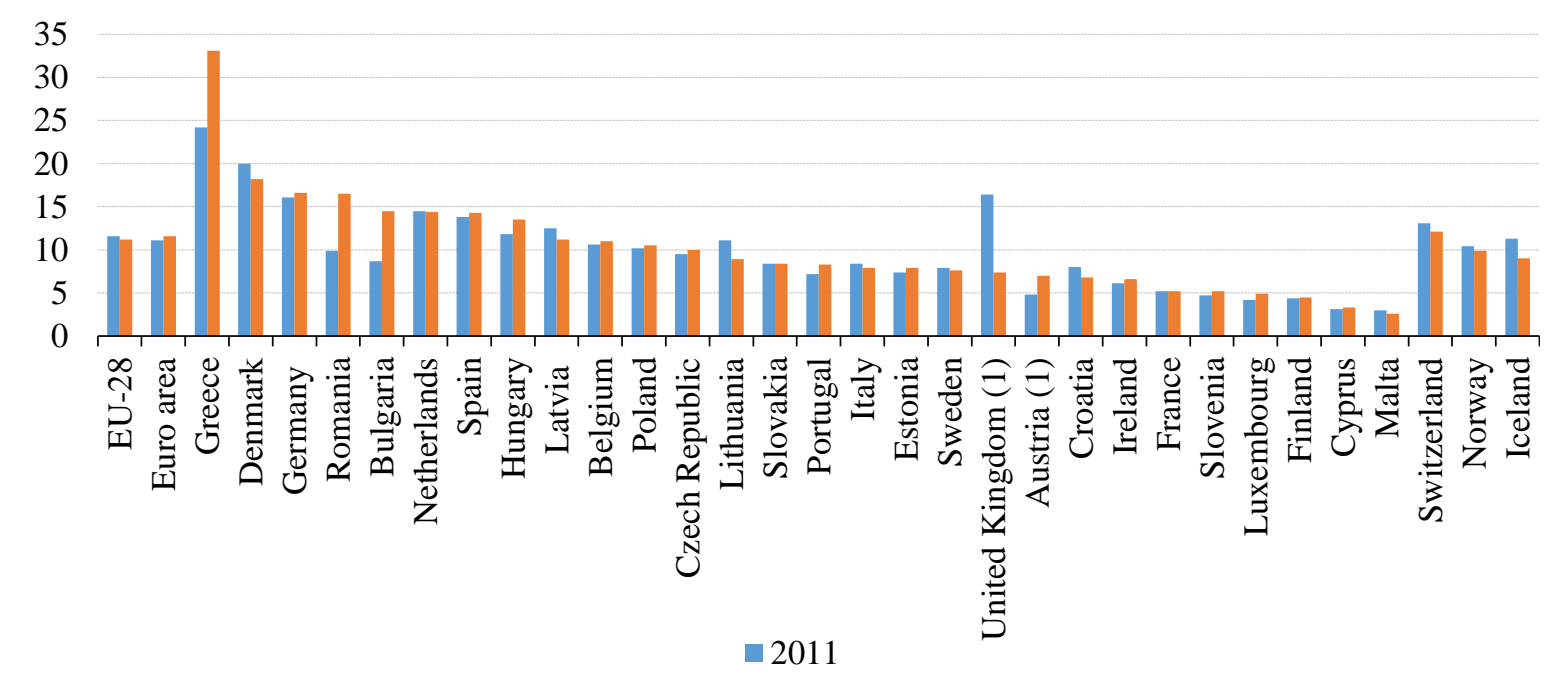

(1) Break in series, 2012

Figure 6. Housing Cost Overburden Rate (\% of population, 2011 and 2012)

Source: Eurostat, 2014. 
The availability of sufficient space in a home is one of the main factors that needs to be assessed to evaluate housing quality and living conditions. This helps reveal the percentage of people that live in overcrowded accommodation, through results based on the number of rooms that belong to a household, the household size, the age of family members and their domestic situation (see Figure 7). In 2012, the highest levels of overcrowded households were observed in Romania (51.6\%), Hungary (47.2\%) and Poland (46.3\%), whereas the lowest levels were seen in Cyprus (2.8\%), the Netherlands (2.5\%) and Belgium (1.6\%). The average across the $28 \mathrm{EU}$ member states was $17.0 \%$. It should be noted that these overcrowding rates might become even higher if households comprised of just one person were eliminated from the overall count. On the other hand, the elimination of these types of household might reduce the rate in countries such as Sweden, France, Denmark, Luxembourg, Germany, Finland, the Netherlands, Belgium, Iceland, Switzerland and Norway, because single people in these nations often live in small flats or studios.

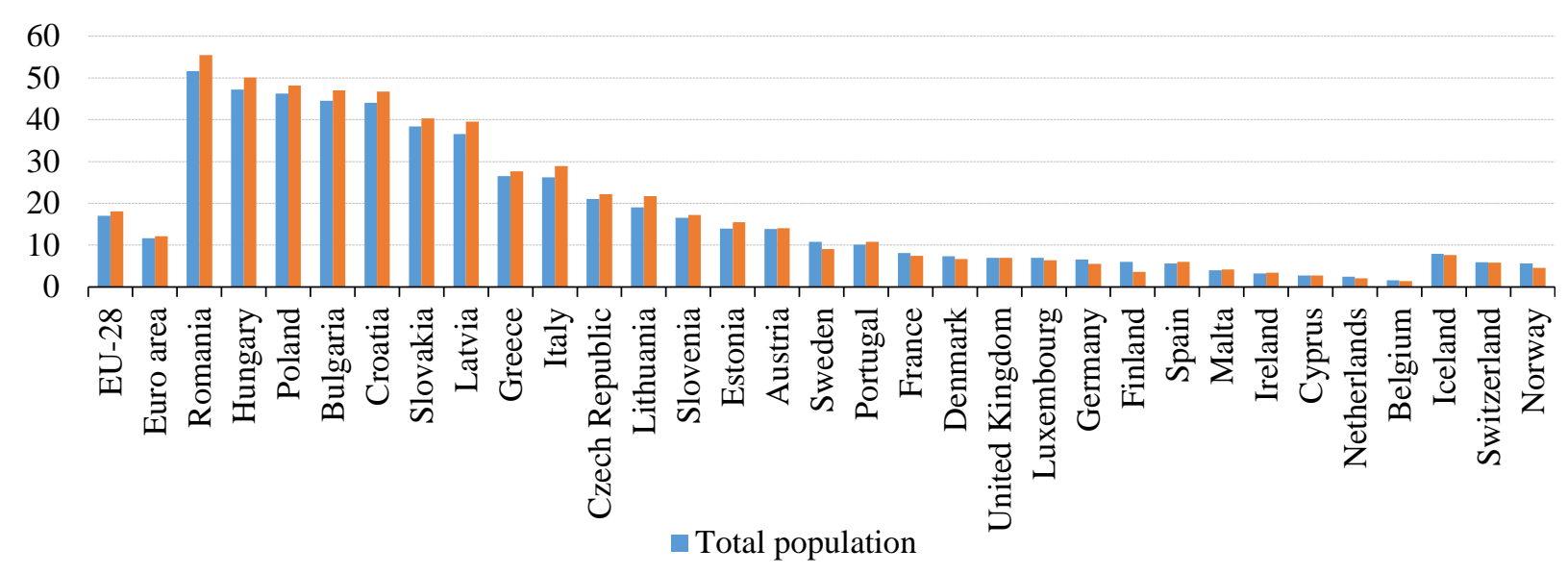

Figure 7. Overcrowding rate (\% of specified population, 2012)

Source: Eurostat, 2014.

Higher levels of household overcrowding in the $28 \mathrm{EU}$ countries are seen in cases in which a household faces poverty (in other words, when equivalised disposable income per person in a household is lower than $60 \%$ of the national median level). In 2012 the biggest differences between overcrowding rates were observed in Hungary (difference of 23.8 percentage points), the Czech Republic (22.4 percentage points), Sweden (21.3 percentage points), Austria (20.4 percentage points) and Norway (17.8 percentage points). On the other hand, the differences in Croatia, Malta and Ireland were lower than 4 percentage points (see Figure 8). 


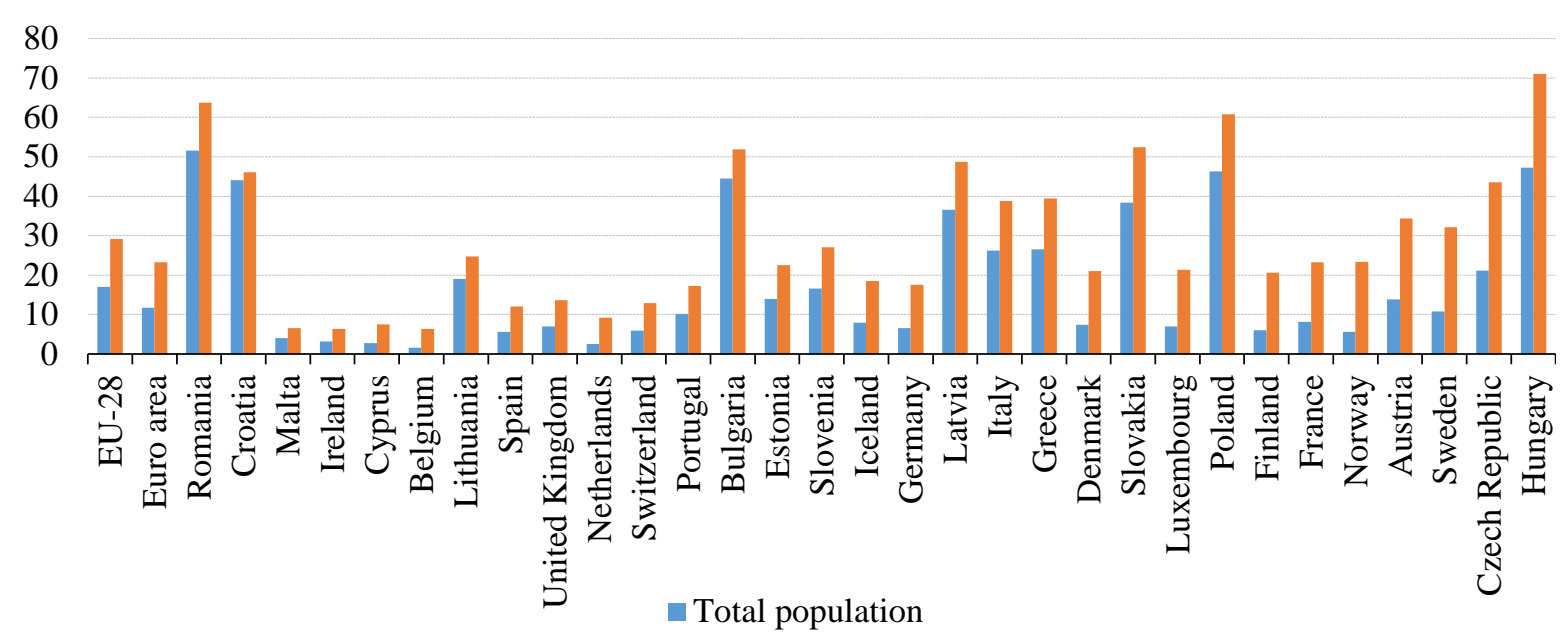

(1) Population below $60 \%$ of median equivalised income

Figure 8. Overcrowding rate by poverty status (\% of specified population, 2012)

Source: Eurostat, 2014.

Eurostat distinguishes one more important indicator - the size of a household, which may reveal the quality of housing in consideration of the living space availability. In 2012, the average size of a dwelling across the 28 EU countries was 102.3 square metres. The average useful space in a household varied from $46.9 \mathrm{~m}^{2}$ in Romania to $68.1 \mathrm{~m}^{2}$ in Lithuania, $69.1 \mathrm{~m}^{2}$ in Latvia and as much as $156.4 \mathrm{~m}^{2}$ in Cyprus (see Figure 9).

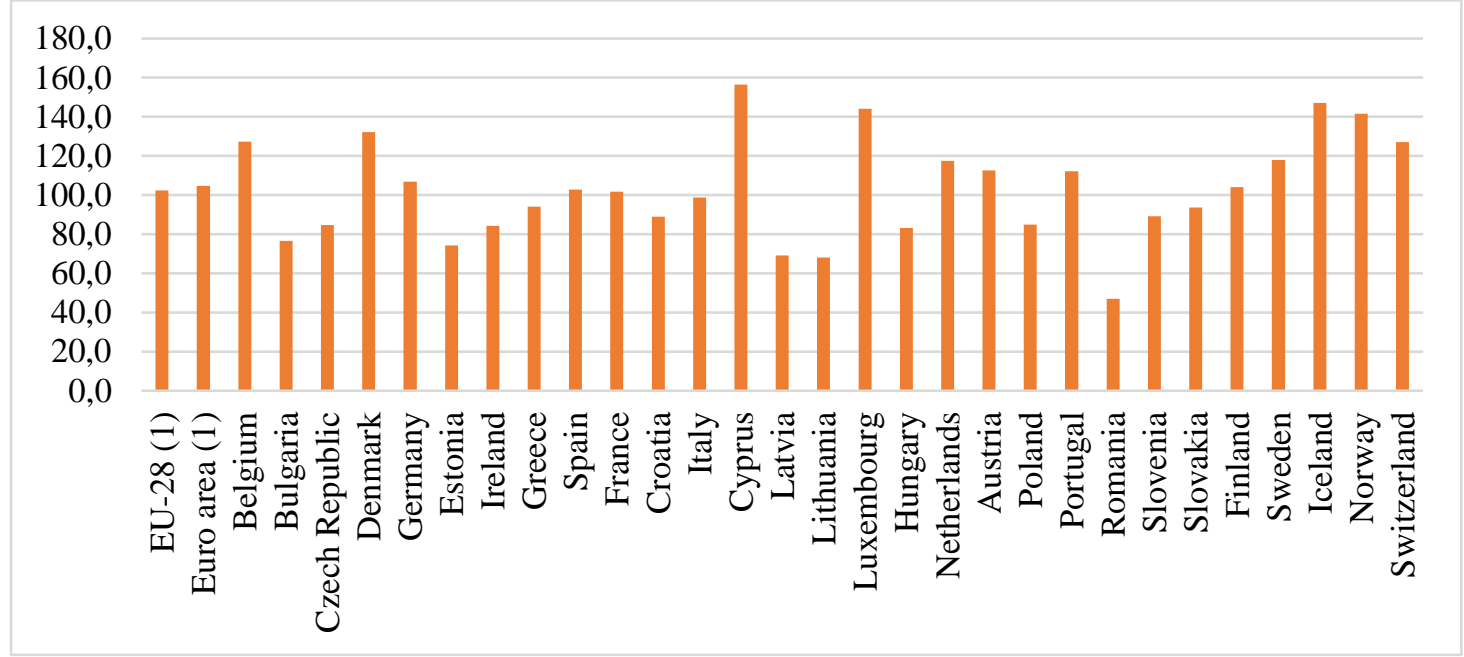

(1) Eurostat estimates

Figure 9. Housing Size $\left(\mathrm{m}^{2}, 2012\right)$

Source: Eurostat, 2014.

According to the results of the study carried out by Mykolas Romeris University and the Vilmorus Market and Opinion Research Centre, $49.40 \%$ of Lithuanian residents lived in a household with an area of 50-79 $\mathrm{m}^{2}$ in 2016 , compared with $30.60 \%$ in households of 30 $49 \mathrm{~m}^{2}, 16.90 \%$ in households larger than $80 \mathrm{~m}^{2}$, and $2.90 \%$ in households smaller than $30 \mathrm{~m}^{2}$ (see Figure 10). 


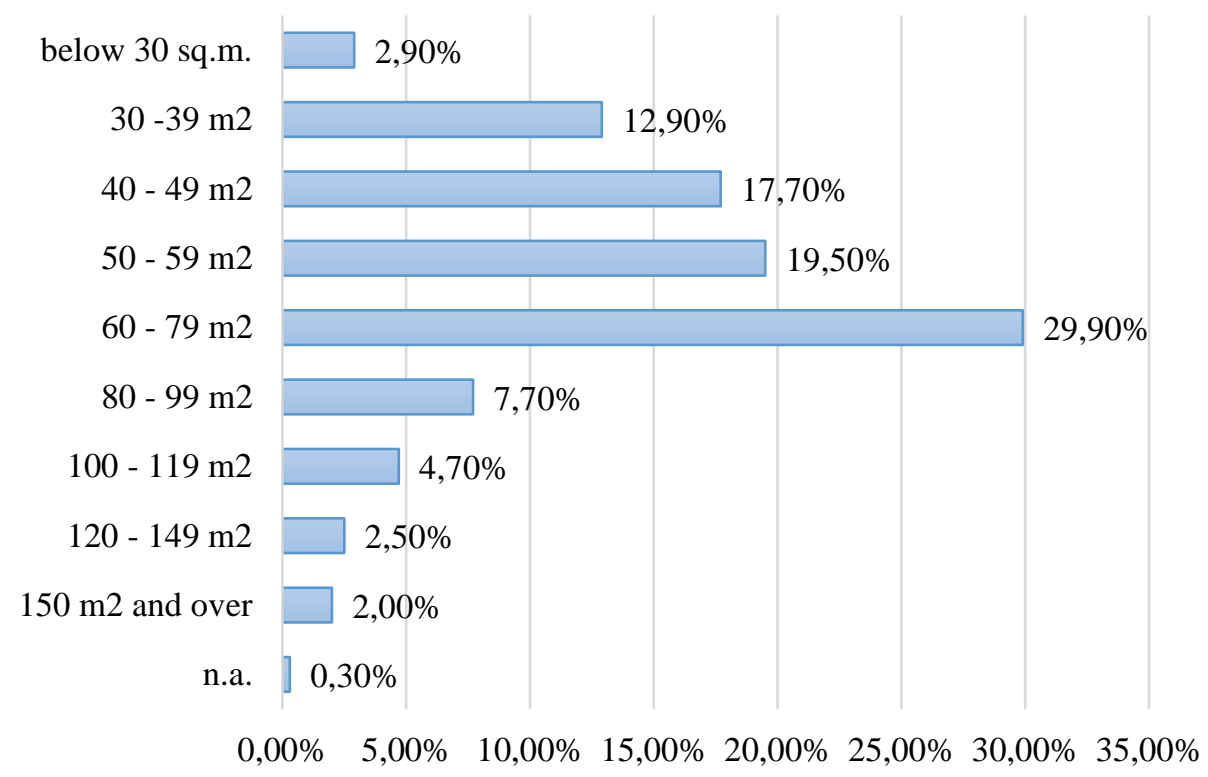

Figure 10. Household Size

Source: Mykolas Romeris University, Vilmorus Market and Opinion Research Centre, 2016.

It should be noted that in Lithuania, each person gets an average space of $30.90 \mathrm{~m}^{2}$ of a dwelling. In Denmark, this figure is $54.36 \mathrm{~m}^{2}$, in Cyprus $48.80 \mathrm{~m}^{2}$ and in Italy $42.92 \mathrm{~m}^{2}$. In Romania, one person gets $21.23 \mathrm{~m}^{2}$, in Slovakia $24.51 \mathrm{~m}^{2}$ and in Poland $24.70 \mathrm{~m}^{2}$, lower levels than in Lithuania (see Figure 11).

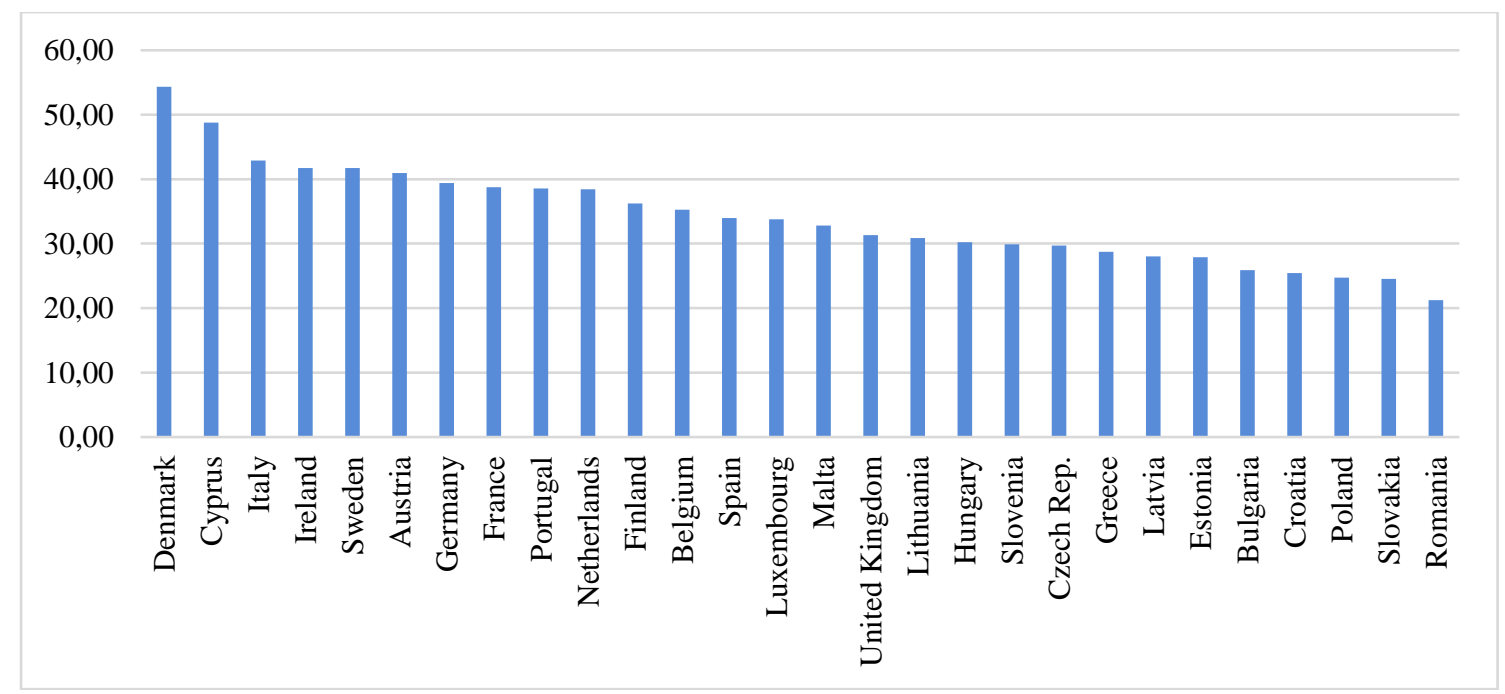

Figure 11. Dwelling Space for a Single Resident $\left(\mathrm{m}^{2}\right)$

Source: Enerdata, 2016.

Insufficient dwelling space and poor amenities in a household are factors used to define one more indicator distinguished by Eurostat - the severe housing deprivation rate ${ }^{1}$. In

\footnotetext{
${ }^{1}$ Severe housing deprivation rate indicates the percentage of people who live in overcrowded dwellings and face at least one of the following issues: a lack of certain basic sanitary facilities (such as a bath, shower or indoor flushing toilet) or problems with the general condition of the dwelling (a leaking roof or the dwelling being too dark).
} 
$2012,79.5 \%$ of people in the EU were declared as not deprived in terms of the "housing dimension", while $15.5 \%$ were found to suffer from one of the dwelling problems, $4.0 \%$ from two, $0.8 \%$ from three and $0.2 \%$ from four (i.e. a leaking roof/damp walls/floors/foundation or rot in the window frames and accommodation being too dark, no bath/shower and no indoor flushing toilet for sole use of the household) (Eurostat, 2014).

In 2012, the severe housing deprivation rate in the EU was $5.1 \%$ and twice as high $(12.6 \%)$ among residents in poverty. The highest severe housing deprivation rates were observed in Romania (22.8\%), Hungary $(17.2 \%)$ and Latvia (16.4\%), with the lowest in the Netherlands, Finland, Belgium and Ireland (less than $1 \%$ of all residents).

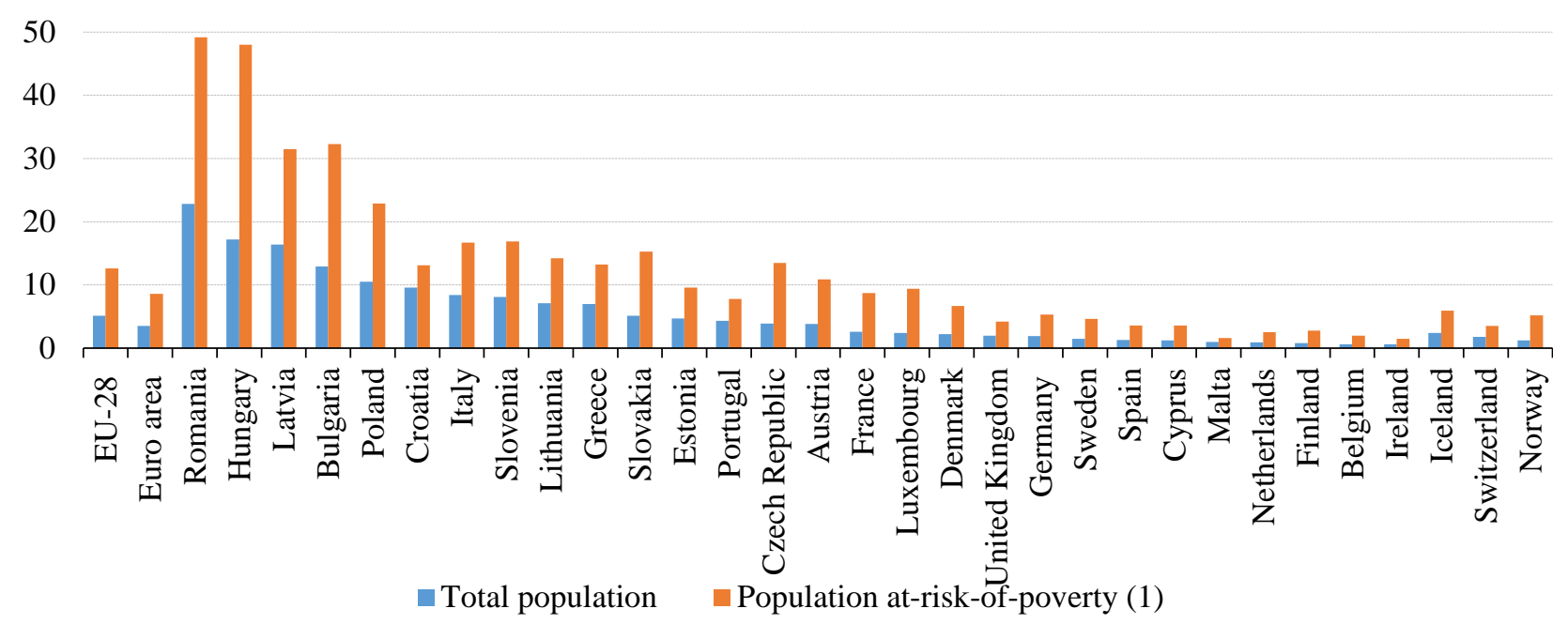

(1) Population below $60 \%$ of median equivalised income

Figure 12. Severe Housing Deprivation Rate Based on the Poverty Rate ((\% of specified population), 2012)

Source: Eurostat, 2014.

A lack of high-quality housing, the housing cost overburden rate for a household, overcrowding in households, insufficient dwelling-space, exploitation and environmental issues, and insufficient income to acquire housing to meet a person's needs are among the main problems faced by both Lithuanians and citizens of other EU member states. If this basic essential demand for satisfactory housing and a good living environment is not met, a good quality of life and other needs are not ensured.

\section{Conclusion}

Socio-economic inequality is one of the most relevant global problems in the contemporary world, because it negatively influences economic development and progress. The concept of socio-economic inequality is rather broad, including aspects of inequalities in income (such as earnings, dividends, pensions, social benefit and allowances), consumption (expenditure on food, accommodation, education, cultural development, recreation, health and durable goods), the distribution of savings and debts, living conditions (wealth, accommodation and life quality) and many other areas. Opportunities to acquire a dwelling place, health insurance and an education, and possibilities with regard to bringing up children and cultural life are unequal for different individuals. In some cases, these factors motivate people, whereas in others they supress a person's capacity for self-realisation and creative potential. They can also increase or prevent economic development in a country. The 
standard means of measuring economic and income-based inequality include various methods involving the distribution of income, but these do not reflect the actual level of inequality. In order to find out the actual level of socio-economic inequality, it makes sense to analyse the distribution of material living conditions (wealth), which might be referred to as the most adequate criterion for assessing socio-economic inequality.

A dwelling place is a significant factor in a person's well-being and helps to ensure a stable society. A lack of high-quality housing, the housing cost overburden rate for a household, overcrowding in households and insufficient dwelling space are among the main issues faced by both Lithuanians and citizens of other EU member states. If this basic essential demand for satisfactory housing and a good living environment is not met, a good quality of life and other needs are not ensured. For a country to form a political system and reduce socio-economic inequality, providing every individual with good living conditions, a stable foundation for future generations and general well-being, it is essential to understand the importance of a dwelling place to a person's quality of life, as well as tendencies in accommodation needs.

\section{References}

Galinienè, B. (1999), Turto ekonomika ir vertinimas (Wealth Economics and Evaluation), Vilnius: BSPB, ISBN 9986-19-339-7.

Galinienè, B. (2005), Turto ir verslo vertinimo sistema: formavimas ir plètros sistema (Wealth and Business Evaluation System: the formation and development of the system), Vilnius: Vilnius University, ISBN 9986-19-663-9.

Enerdata (2016), Average floor area per capita, http://www.entranze.enerdata.eu/ (referred on 20/05/2016).

European Commission (2014), Komisijos komunikatas Europos parlamentui, Tarybai, Europos ekonomikos ir socialinių reikalų komitetui ir Regionų komitetui / Pažangaus, tvaraus ir integracinio augimo strategijos „Europa 2020“ rezultatu apžvalga (Communication from the Commission to the European Parliament, the Council, the European Economic and Social Committee and the Committee of the Regions / Taking stock of the Europe 2020 strategy for smart, sustainable and inclusive growth), http://ec.europa.eu/europe2020/pdf/europe2020stocktaking_lt.pdf (referred on 05/04/2016)

Eurostat (2014), Housing conditions, <http://ec.europa.eu/eurostat/statisticsexplained/index.php/ Housing_conditions> (referred on 01/04/2015).

Lipnevič, A. (2012), Būsto politikos raida Lietuvoje (Evolution of Housing policy in Lithuania), Societal Innovations for Global Growth, Vilnius: Mykolas Romeris University, No. 1(1), ISSN 2335-2450.

Mykolas Romeris University, Market and Opinion Research Centre „Vilmorus“, Būstas, gyvenimo sąlygos, turtas (Housing, Living Conditions and Wealth), 2016.

Pakalniškis, V., Papirtis, L. V. et al. (2008), Civilinė teisè. Bendroji dalis (Civil law. General Part), Vilnius: Mykolas Romeris University, ISBN 978-9955-19-060-8.

Ragauskienè, E. (2011), Valstybès turto ekonominè analizè ir valdymo transformacija (Economic analysis of the State Property Management and Transformation), Doctoral thesis, Vilnius: Vilnius University.

Rakauskienė, O. G., Štreimikienè, D., Servetkienė, V. et al. (2015), Gyvenimo kokybès matavimo rodikliu sistema ir vertinimo modelis (Quality of Life Measurement Indicator System and Assessment Model), Vilnius: Mykolas Romeris University, 760 p., ISBN 978-19-713-3. 
Salverda, W., Nolan, B., Smeeding, T. M. et al. (2013), The Oxford Hanbook of Economic Inequality, Oxford University Press, 736 p., ISBN 978-0-19-960606-1.

Stiglitz, J. E., Sen, A., Fitoussi, J. P. (2010), Report by the Commission on the Measurement of Economic Performance and Social Progress, Paris: Commission on the Measurement of Economic Performance and Social Progress, http://www.stiglitz-senfitoussi.fr/documents/rapport_anglais.pdf (referred on 07/05/2016). 